\title{
Dynamic Changes Analysis of Land Resource Balance in North Maluku Province, Indonesia
}

\author{
Elya Pratiwi Isti Faroh ${ }^{1}$, Fatih Cinderaswari Puspaningrani ${ }^{1}$, Gema Reinadova ${ }^{1}$, Muhammad Rais Akbar ${ }^{1}$, \\ Novanna Dwi Septyo Anggraeni ${ }^{1}$, Oki Silvie Wildiyanti ${ }^{1}$, Utia Kafafa ${ }^{1}$, and Ratih Fitria Putri ${ }^{1, *}$
}

${ }^{1}$ Department of Environmental Geography, Faculty of Geography, Universitas Gadjah Mada, Sekip Utara, Bulaksumur, Yogyakarta 55281, Indonesia

*Corresponding author: ratihfitria.putri@ugm.ac.id

\section{KEYWORDS \\ Change \\ Land}

Land carrying capacity

Land resource balance

Land use

SUBMITTED 29 April 2020

REVISED 12 June 2020

ACCEPTED 19 June 2020

\begin{abstract}
Land resources are part of nature related to the availability of water, nutrients, and food that are dynamic and play an important role in the lives of living creatures, including humans. From time to time, land use experiences changes in response to human activities that benefit their lives. This research was conducted to determine trends in land use change in North Maluku Province, Indonesia, as well as to find out the land resource balance and land carrying capacity in the province. The methods comprised a simple descriptive and quantitative analysis along with spatial analysis using GIS. The results showed that land use in North Maluku Province for paddy fields was higher than that for nonpaddy land use. However, the increase in non-paddy land use was greater every year compared with the increase in paddy land use. The land resource balance in North Maluku Province in 2010-2018 also showed a decrease in non-agricultural protected forest, by 150,895.79 ha, as well as an increase in 4,286 ha of irrigated paddy fields. Meanwhile, the land carrying capacity during this same period was found to be declining at a rate of $6 \%$ per year, based on the population increase each year within a permanent land area.
\end{abstract}

(c) The Author(s) 2020. This article is distributed under a Creative Commons Attribution-ShareAlike 4.0 International license.

\section{INTRODUCTION}

Land is part of the earth's surface as a physical environment that affects its use, such as climate relief/topography, geological aspects, and hydrology, which humans make use of for various purposes. Land use is divided into two major groups, namely agricultural and non-agricultural land use. Land use of agricultural land includes uses such as dry fields, paddy fields, coffee plantations, rubber plantations, grasslands, production forests, protected forests, and so on. Meanwhile, the use of non-agricultural land can be divided into urban and rural uses, such as settlements, industry, recreation, mining, and so on.

The existence of a very large population explosion in Indonesia, has made humans compete with each other in order to fulfil their daily needs, including land used for catching rainwater, agriculture, and settlements. Almost all physical development sectors require land, be it agriculture, forestry, housing, industry, mining, or transportation. The function of land for the community is generally for shelter or as a source of livelihood. Unlike farmers, the private sector and the government have their own goals regarding land. The existence of various interrelated interests in land use, results in overlapping interests between farmers, private parties, and the government in utilizing land. According to Barkley (1986), institutional factors that influence land use patterns are those related to the social culture and rules of the community, including, in this case, the rules or regulations of the local government.
Land use by humans has changed from time to time in accordance with how the dynamics and sustenance of their lives. Human behavior in utilizing land can change its existing physical conditions, in ways that can change it in a better direction or a worse direction. Changes in land use are defined as changes for other uses caused by factors that broadly include the need to meet the needs of an increasing population and increasing demands for a better quality of life (Fitrianingsih 2017). Changes of land use are an increase in land use from one type of use to another, followed by a decrease in other types of land use over time, or changes in land use at different periods (Wahyunto 2001).

Changes in land use from agricultural land to nonagricultural land are not just the physical phenomena of decreasing land area, but rather dynamic phenomena involving aspects of human life because they are aggregately related to changes in the economic, socio-cultural, and political orientation of the community. Land conversion from agriculture to non-agriculture occurs widely in line with development policies that emphasize the aspect of growth through investment facilities to investors (Widjanarko et al. 2006). Land conversion can also be caused by low farmer exchange rates, which remove incentives for farmers to continue to live from their farming activities, so they tend to convert their plantations (Ashari 2003).

In the last two decades, the land and waters of North Maluku Province, Indonesia, have been filled with extractive industry activities, ranging from mining, oil palm plan- 
tations, to industrial timber plantations. As a result, agricultural land and plantations for farmers, as well as coastal and marine areas for fishermen, continue to be eroded in the face of the expansion of the extractive industry (Jaringan Advokasi Tambang 2020). Another issue in North Maluku is land conflict in forest areas. This land conflict has occurred in the investment area of the Kelapa Genjah plantation, Akelamo Village, Oba Tengah Subdistrict, Tidore Municipality, which involved the community, local government, and PT. Tidore Sejahtera Bersama. Conflicts have also occurred in the Jikolamono tourism land located in Akehuda and Takome Subdistricts, Ternate Municipality. Both of these problems involving the community, government, and private sector have been occurring since 2016 (Malut Post 2017). This conflict occurs because of land use change that was not approved by several parties for one reason or another. This fact makes it imperative to analyze and determine the spatial distribution and trends in land use change and land carrying capacity in North Maluku Province.

\section{MATERIALS AND METHODS}

\subsection{Study area}

The case study of this research was North Maluku Province. This province is an archipelago located $124^{\circ}$ east longitude and $3^{\circ}$ north to $3^{\circ}$ south latitude. There are about 353 large and small islands, both inhabited and uninhabited in this region. The biggest and most important island is Halmahera, following which are a number of other islands, including Obi, Sula, Morotai, Bacan, Makian, Ternate, and Tidore. The reasons for taking this research location include North Maluku Province having abundant land resources in the agriculture, plantation, and fisheries sectors, although in the last two decades, the land and waters of North Maluku have experienced changes in use due to extractive industry activities, ranging from mining, oil palm plantations, to industrial timber plantations.

\subsection{Data collection and analysis techniques}

The data sources used for the analysis of land resources in North Maluku were obtained from statistical data published by Indonesia's official statistics bureau (Statistics Indonesia 2011, 2016, 2019). The methodology of the analysis of land resources in North Maluku Province was carried out in a simple descriptive and quantitative manner based on theories and hypotheses regarding the calculation of land carrying capacity and preparation of land resource balance sheets. In addition, an analysis was carried out using the spatial analysis method of the map that was made.

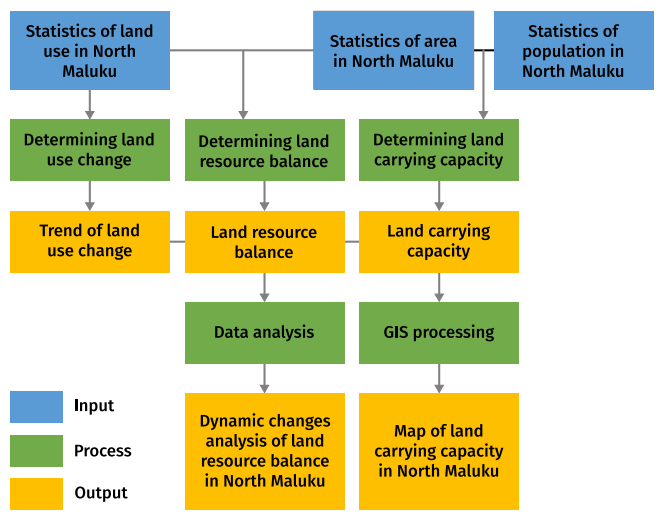

FIGURE 1. Research flowchart.

\subsubsection{Land carrying capacity}

Land carrying capacity based on capacity was calculated according to the variable area of land function divided by the number of the existing population, with the calculation formula shown in Equation 1 (Muta'ali 2014 in Dinas Lingkungan Hidup 2018):

$$
\begin{aligned}
A & =\mathrm{L} / \mathrm{P} \\
A & =\text { Land carrying capacity } \\
L & =\text { Land area (ha) } \\
P & =\text { Total population (person) }
\end{aligned}
$$

If the carrying capacity of the land is lower than the determined value, this means that the population in the area has exceeded the carrying capacity of the environment.

\subsection{Land resource balance}

The compilation of land resource balance was prepared to evaluate the results of the inventory in two year periods. This balance sheet is presented descriptively in a table format that contains the potential reserves (left column) and the utilization (right column), also known as the activa and pasiva columns.

\subsubsection{Geographic information system (GIS)}

The Geographic Information System (GIS) is a computer system used for the acquisition and verification, compilation, storage, change (updating) management and exchange, manipulation, summons and presentation, and analysis of geographical data. Data processing was performed using the ArcGIS software. The program was also used to present spatial distribution data.

\subsection{Research design}

The conducted research was designed as shown in the flowchart in Figure 1.

\section{RESULTS AND DISCUSSION}

\subsection{Land use trend in 2010-2014}

Land use is a dynamic area, wherein land use changes become an indicator of the development of an area. These changes in land use can be caused by various factors that are interrelated with one another and potentially affect other surroundings (Husin and Herwangi 2018).

\section{The Comparison Between Paddy and Non-Paddy Fields Land Use in North Maluku}

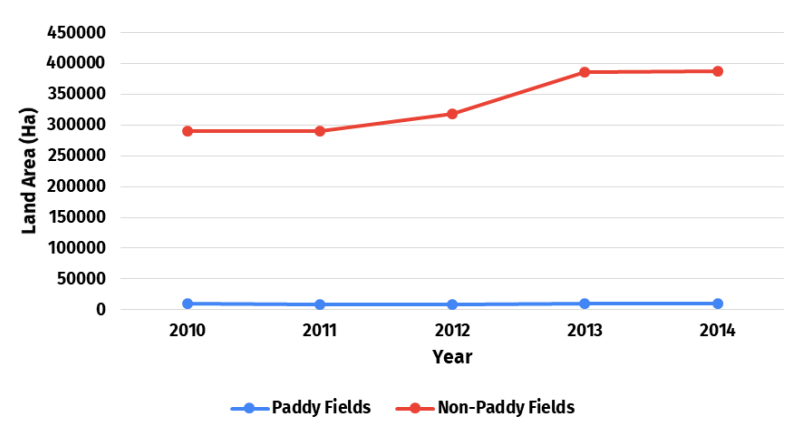

FIGURE 2. The comparison between paddy and non-paddy field land use in North Maluku, 2010-2014. 


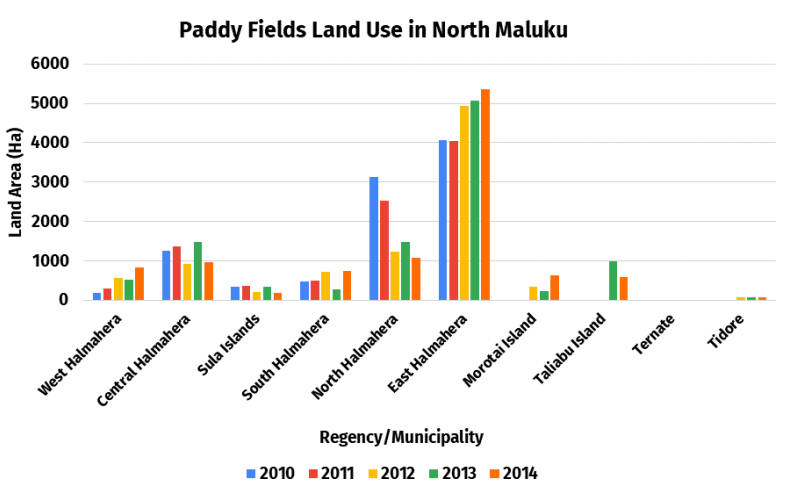

(a)

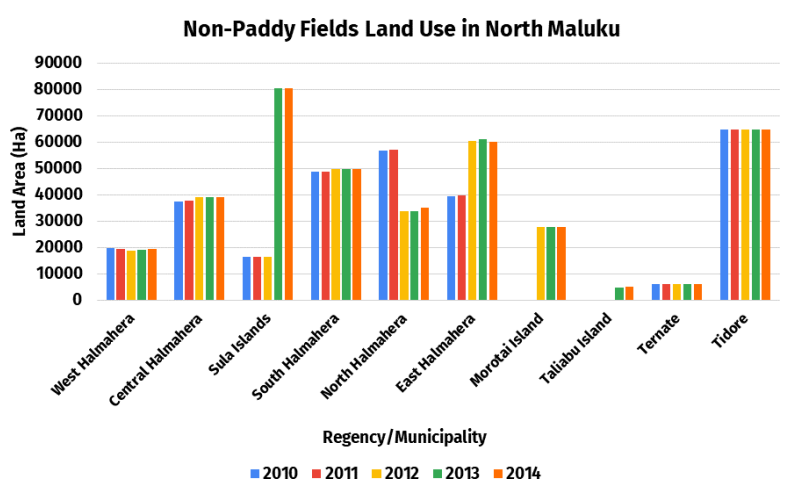

(b)

FIGURE 3. (a) Paddy field land use and (b) non-paddy field land use in North Maluku, 2010-2014.

Figure 2 shows the growth of land use change from 2010 to 2014. The extent of non-paddy fields was larger compared with the area of paddy fields. Paddy fields in North Maluku Province covered an area of 9,000-10,000 ha, while non-paddy fields covered 20,000-30,000 ha. The highest increase occurred in favor of non-paddy fields, in 2013. On the other hand, paddy fields from 2010 to 2014 had a steady increase. The use of non-paddy fields here is identified as a dry field, unirrigated agricultural field, and temporarily unused land.

The distribution of wet fields for each regency in North Maluku Province was found to contain some level of inequality (Figure 3a). The widest area of wet field was in East Halmahera Regency, whereas Ternate Municipality contained the narrowest. East Halmahera having a higher extent of wet field can be explained by the regency's area being greater than the other regions. East Halmahera has

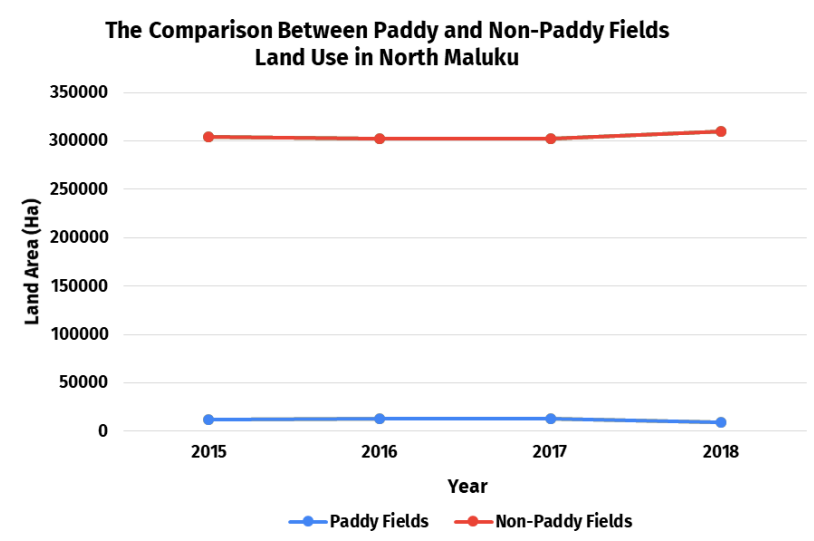

FIGURE 4. The comparison between paddy and non-paddy field land use in North Maluku 2015-2018.

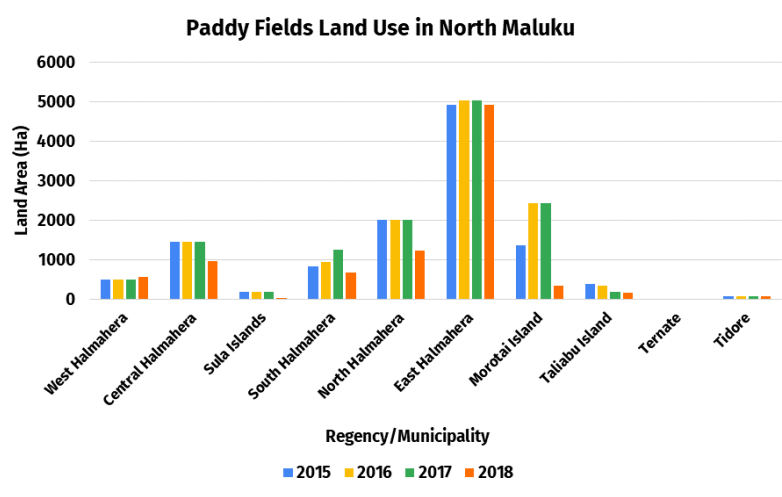

(a)

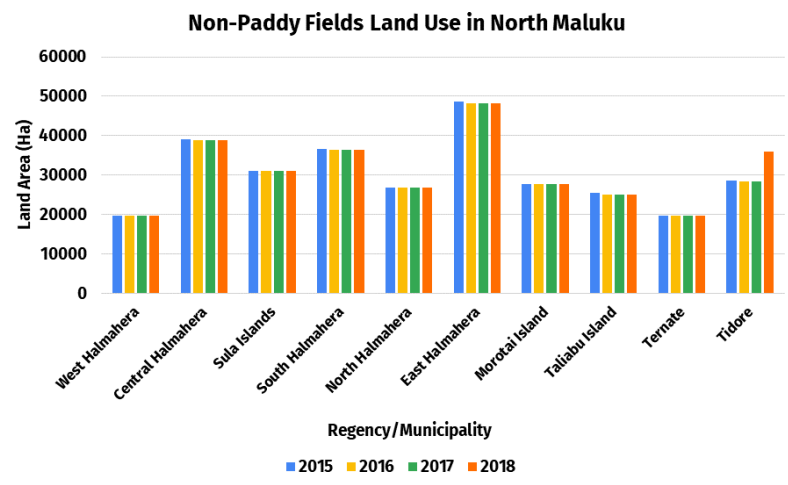

(b)

FIGURE 5. (a) Paddy field land use and (b) non-paddy field land use in North Maluku, 2015-2018.

also become a transmigration area and some people use the land given for cultivation.

As Figure 3b shows, the distribution of non-paddy fields for each district in North Maluku Province was fairly distributed. The graph shown does not show any imbalances for non-paddy field land use. However, for Taliabu Island and Ternate, they were found to contain a small area of non-paddy field, since these two districts have a narrow area compared with their counterparts.

\subsection{Land use trend in 2015-2018}

North Maluku, which consists of Ternate, Tidore, West Halmahera, East Halmahera, North Halmahera, South Halmahera, Sula Islands, Morotai Island, and Taliabu Island, is mostly mountainous and hilly. In some parts of the area, there have been many changes in land use. However, the development of North Maluku is not too dynamic, so changes in land use do not exceed the limits or exceed the carrying capacity in that area.

Figure 4 shows that paddy field land use in North Maluku was lower than non-paddy field land use. This was influenced by the type of land present in North Maluku, which is dry and therefore not suitable for paddy fields. According to Bank Indonesia (2013), North Maluku's main commodities are cloves, nutmeg, copra, and coffee, while commodities originating from paddy fields are found only in East Halmahera.

Within 4 years (2015-2018), there was a slight decrease in paddy field land use, due to the conversion of paddy fields into non-agricultural land (for example being converted into settlements). Meanwhile, non-paddy field land use increased slightly because of an increase in demand related to the main commodity plantations in North Maluku, especially for export purposes. The decrease in paddy field land use and increase in non-paddy field land use that oc- 
TABLE 1. Land resource balance of North Maluku Province, 2010 and 2018.

\begin{tabular}{|c|c|c|c|c|c|c|}
\hline \multicolumn{3}{|c|}{ ACTIVA 2010} & \multicolumn{3}{|c|}{ PASIVA 2018} & \multirow[t]{2}{*}{ Addition/Reduction } \\
\hline Initial state & Land use & Area (ha) & Final state & Land use & Area (ha) & \\
\hline & Agriculture & 277346 & & Agriculture & 325093 & 47747 \\
\hline 1 & Dry field/plantation & 202272 & 1 & Dry field/plantation & 223526 & 21254 \\
\hline 2 & Unirrigated agricultural field & 65596 & 2 & Unirrigated agricultural field & 93903 & 28307 \\
\hline 3 & Irrigated paddy field & 8118 & 3 & Irrigated paddy field & 3832 & -4286 \\
\hline \multirow[t]{2}{*}{4} & Unirrigated paddy field & 1360 & 4 & Unirrigated paddy field & 3832 & 2472 \\
\hline & Non-agriculture & 1180665 & & Non-agriculture & 1132918 & -47747 \\
\hline 1 & Protection forest & 729893 & 1 & Protection forest & 578998.2 & -150895 \\
\hline 2 & Temporarily unused land & 18569 & 2 & Temporarily unused land & 20754 & 2185 \\
\hline 3 & Others & 432202 & 3 & Others & 533166 & 100964 \\
\hline TOTAL & & 1458011 & & & 1458011 & 0 \\
\hline
\end{tabular}

curred was not significant and consequently did not have a significant impact.

Figure 5 shows that paddy field land use varied between regencies in North Maluku in 2015-2018. This paddy field land use was most common in East Halmahera, with agricultural foodstuffs such as paddy (rice) being the sector with the largest contribution to the economy in that regency (Bank Indonesia 2013). Ternate did not have paddy fields because it is the economic center of North Maluku, so the region is instead dominated by the non-agricultural sector. Paddy field land use was found to decrease in several regencies, which is generally caused by an increase in the need for a place or space that is inversely proportional to the limited availability of land, causing changes in land use.

Land use needs to be analyzed through spatial and temporal means to determine changes in land use in a place (Assyakur et al. 2008). From 2015 to 2018, non-paddy field land use tended to be stable, with an even trend among all regencies of little change from 2017 to 2018. Non-paddy field land use tends to be higher compared with paddy field land use because of the importance of developing North Maluku's main commodities, especially for exporting.

There was a slight change in paddy and non-paddy field land use. This can have a number of negative impacts, such as increased erosion, environmental degradation, and other environmental damage. The changes in land use from 2015 to 2018 in North Maluku were not significant and did not exceed land capability, but preventive action is needed from both the government and the community. According

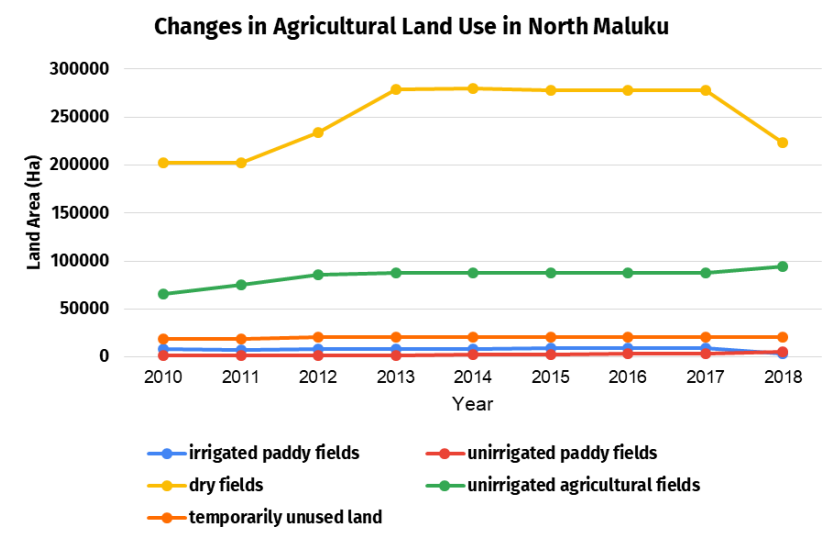

FIGURE 6. Changes in agricultural land use in North Maluku 2010-2018. to Munibah et al. (2010), there is a need for communication from various parties to reach an agreement related to changes in land use in order to minimize the occurrence of environmental damage.

\subsection{Land resource balance}

The data and information presented in the balance sheet are expected to help policymakers in formulating policies in natural resource management that are in line with the principles of sustainable development. Agricultural land resources are one of the important resources that must be managed properly because agricultural land produces food that is needed by everyone. Unattractive agricultural activities for the younger generation, as well as competition for land use between the agricultural and non-agricultural sectors (such as infrastructure, industry, and urban/settlement uses) turn into technical and nontechnical factors that become obstacles in agricultural development in the future.

Based on the data shown in Table 1, it can be seen that there were changes in the area of agricultural and non-agricultural land between 2010 and 2018. Several land areas had increased by the latter stage. These were dry fields, unirrigated agricultural fields, unirrigated paddy fields, temporarily unused land, and other land uses. Conversely, areas composed of irrigated paddy fields and protected forest decreased. Protected forest had the largest area reduction, by $150,895.79$ ha, whereas unirrigated agricultural field had the largest area addition, with 28,307 ha.

Irrigated paddy field was the only agricultural land that declined. This can threaten food availability, especially that of rice, for the surrounding population in North Maluku. Their food sources are likely to be fulfilled by dry fields and unirrigated agricultural fields that are usually used to grow basic food crops such as corn, sago, cassava, etc.

According to a report by Agus and Mulyani (2006) that rice self-sufficiency could be maintained until 2025 if the rate of land conversion could be inhibited to around 75,000 ha/year and there were additional new paddy fields of around 100,000 ha/year. So, based on data from the processing of the land balance, North Maluku Province is predicted to be not inadequate in overcoming rice selfsufficiency until 2025.

Furthermore, the only non-agricultural land that had declined by 2018 was protected forest. The cause of the reduction in protected forest area is unknown. As a natu- 


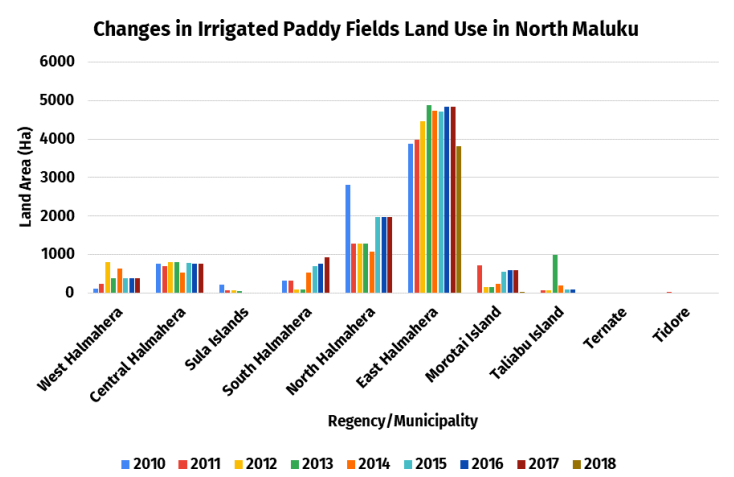

(a)

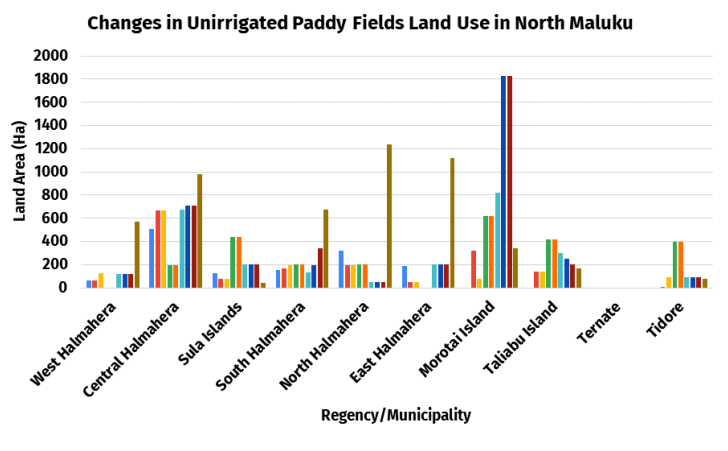

(b)

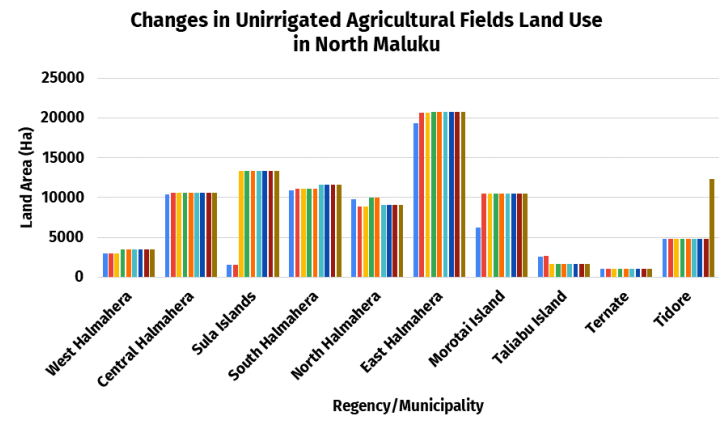

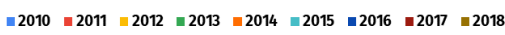

(c)

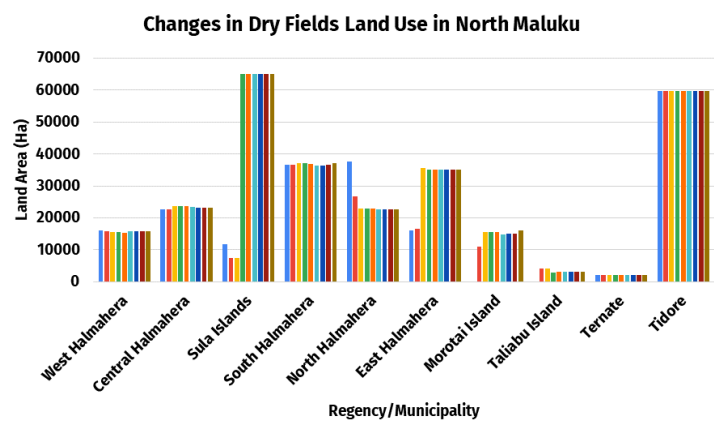

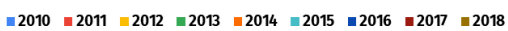

(d)

FIGURE 7. Changes in (a) irrigated paddy field, (b) unirrigated paddy field, (c) unirrigated agricultural field, and (d) dry field land uses in North Maluku, 2010-2018.

ral resource, forests are a source of various biological, nonbiological objects and services that have strategic value to support the interests of national and regional development.

The availability of renewable natural resources is unlimited, so forest management and utilization must be carried out optimally and sustainably. This will guarantee the existence of roles and functions of forest resources. The basis of forest management requires data, as outlined in the Forest Resource Balance. Calculation and analysis of Forest
Resource Balance can be used to determine the regional natural resource balance within a certain period, and thus explain the reserves, changes, and the rest of the land and forest resources. As a result, resources can be used more effectively, efficiently, and sustainably.

\subsection{Change in land use analysis}

Agriculture is one of the main sectors that support the economy in North Maluku. From 2010 to 2018, the agriculture sector was the highest in absorbing labor, even though the area of agriculture has continued to decline at a slow pace every year. This is caused by the changes in the use of agricultural land in North Maluku Province (Figure 6).

Based on the graph in Figure 6, it can be seen that dry fields encompassed the largest area in North Maluku Province, followed by unirrigated agricultural fields, temporarily unused land, irrigated paddy fields, and nonirrigated paddy fields. The agricultural sector in North Maluku was dominated by non-paddy fields. According to the Soil Research and Development Center (2000), North Maluku has more dry land than wetland, so land management for paddy fields is much more difficult.

Agricultural land in North Maluku experienced a fairly stable change during the period of 2010-2018, except in 2018 there was some decline in agricultural land use, namely that of dry fields. This is due to an increase in the amount of vacant land or land that is temporarily unused, which may occur due to riots and natural disasters in that year, and hence agricultural activities are disrupted.

The area of paddy fields in North Maluku has fluctuated, but there was a tendency of this land use type to decrease in area from 2010 to 2018. The district with the most irrigated paddy fields until 2018 was East Halmahera whereas that with the least was Morotai Island, while other districts began to experience losses of paddy fields.

Ternate and Tidore do not have irrigated paddy fields because they are urban areas with services and manufacturing as their main sectors. Other districts tended to experience reductions and depletion in 2018 due to the conversion of paddy fields to non-paddy fields, or paddy fields to settlements following a population increase in North Maluku due to the transmigration program.

A fluctuation change was also found in the use of unirrigated paddy fields, although it tended to decrease in 20102018 (Figure 7). This decline was due to the conversion of land to non-paddy and non-agricultural land. The largest irrigated paddy fields in 2018 were in North Halmahera, followed by East Halmahera and Central Halmahera. Morotai Island had the most extensive area of unirrigated paddy fields between 2016 and 2017; this change may have occurred due to climate change or increased irrigation infrastructure. Indonesia's Meteorology, Climatology, and Geophysical Agency, and specifically its Baabullah Ternate station, has noted changes in the climate of North Maluku, among others, as seen in the increase in average temperatures each year. Anomalous conditions in 2015 rose by $0.6^{\circ} \mathrm{C}$ compared with the normal conditions of $28^{\circ} \mathrm{C}$ in 2016 , and up again by $1.02^{\circ} \mathrm{C}$. In 2017 , it rose $0.06^{\circ} \mathrm{C}$, followed by a $0.9^{\circ} \mathrm{C}$ increase in 2018. Additionally, there has been a tendency of rising sea temperatures to change wind circulation patterns and automatically cause seasonal changes. North Halmahera has the most extensive unirrigated paddy fields because of the conditions of the area. The extensive addition over the previous year was also because of government policies to increase agricultural output to support the community's economy. The largest decrease in unir- 
rigated paddy fields occurred on Morotai Island, as more paddy fields were turned into irrigated paddy fields to increase crop yields. In contrast to the area containing irrigated paddy fields, in the Tidore, there was an area of unirrigated paddy fields, which shows that the food supply is supported by unirrigated paddy fields in the municipality.

The area containing unirrigated agricultural fields in North Maluku was greater than that containing paddy fields, and tended to be stable in each district from 2010 to 2018. This is due to the nature of the land in North
Maluku, which is dry, making it more suitable for dry agriculture. The largest area of unirrigated agricultural fields was in East Halmahera and the smallest was in Ternate. The increase in the number of fields in the Tidore in 2018 was the result of the government's new policy to grow upland rice in the dry land, in addition to Ternate and Tidore making spices their main commodities, both of which are crops grown in the unirrigated agricultural fields.

The land area composed of dry fields or plantations was quite high in the North Maluku region and tended to

TABLE 2. Balance of land use changes in agricultural land in North Maluku Province.

\begin{tabular}{|c|c|c|c|c|c|c|}
\hline Number & Regency/municipality & Land use type & Area, 2010 (ha) & Area, 2018 (ha) & Land use change addition (ha) & Land use change reduction (ha) \\
\hline \multirow[t]{5}{*}{1} & West Halmahera & Dry field/plantation & 16175 & 15700 & 0 & 475 \\
\hline & & Unirrigated agricultural field & 2951 & 3509 & 558 & 0 \\
\hline & & Irrigated paddy field & 121 & 0 & 0 & 121 \\
\hline & & Unirrigated paddy field & 65 & 572 & 507 & 0 \\
\hline & & Temporarily unused land & 527 & 527 & 0 & 0 \\
\hline \multirow[t]{5}{*}{2} & Central Halmahera & Dry field/plantation & 22537 & 23220 & 683 & 0 \\
\hline & & Unirrigated agricultural field & 10382 & 10584 & 202 & 0 \\
\hline & & Irrigated paddy field & 750 & 0 & 0 & 750 \\
\hline & & Unirrigated paddy field & 507 & 978 & 471 & 0 \\
\hline & & Temporarily unused land & 4884 & 5004 & 120 & 0 \\
\hline \multirow[t]{5}{*}{3} & Sula Islands & Dry field/plantation & 11681 & 65023 & 53342 & 0 \\
\hline & & Unirrigated agricultural field & 1544 & 13352 & 11808 & 0 \\
\hline & & Irrigated paddy field & 225 & 0 & 0 & 225 \\
\hline & & Unirrigated paddy field & 125 & 43 & 0 & 82 \\
\hline & & Temporarily unused land & 235 & 2023 & 1788 & 0 \\
\hline \multirow[t]{5}{*}{4} & South Halmahera & Dry field/plantation & 36491 & 37104 & 613 & 0 \\
\hline & & Unirrigated agricultural field & 10905 & 11657 & 752 & 0 \\
\hline & & Irrigated paddy field & 331 & 0 & 0 & 331 \\
\hline & & Unirrigated paddy field & 157 & 674 & 517 & 0 \\
\hline & & Temporarily unused land & 1520 & 1567 & 47 & 0 \\
\hline \multirow[t]{5}{*}{5} & North Halmahera & Dry field/plantation & 37578 & 22784 & 0 & 14794 \\
\hline & & Unirrigated agricultural field & 9787 & 9124 & 0 & 663 \\
\hline & & Irrigated paddy field & 2806 & 0 & 0 & 2806 \\
\hline & & Unirrigated paddy field & 321 & 1238 & 917 & 0 \\
\hline & & Temporarily unused land & 2305 & 2031 & 0 & 274 \\
\hline \multirow[t]{5}{*}{6} & East Halmahera & Dry field/plantation & 16057 & 35097 & 19040 & 0 \\
\hline & & Unirrigated agricultural field & 19314 & 20794 & 1480 & 0 \\
\hline & & Irrigated paddy field & 3885 & 3816 & 0 & 69 \\
\hline & & Unirrigated paddy field & 185 & 3816 & 3631 & 0 \\
\hline & & Temporarily unused land & 4033 & 4275 & 242 & 0 \\
\hline \multirow[t]{5}{*}{7} & Morotai Island & Dry field/plantation & 0 & 16101 & 16101 & 0 \\
\hline & & Unirrigated agricultural field & 6203 & 10525 & 4322 & 0 \\
\hline & & Irrigated paddy field & 0 & 16 & 16 & 0 \\
\hline & & Unirrigated paddy field & 0 & 16 & 16 & 0 \\
\hline & & Temporarily unused land & 1217 & 1479 & 262 & 0 \\
\hline \multirow[t]{5}{*}{8} & Taliabu Island & Dry field/plantation & 0 & 2994 & 2994 & 0 \\
\hline & & Unirrigated agricultural field & 2624 & 1699 & 0 & 925 \\
\hline & & Irrigated paddy field & 0 & 0 & 0 & 0 \\
\hline & & Unirrigated paddy field & 0 & 166 & 166 & 0 \\
\hline & & Temporarily unused land & 430 & 278 & 0 & 152 \\
\hline \multirow[t]{5}{*}{9} & Ternate & Dry field/plantation & 2060 & 2060 & 0 & 0 \\
\hline & & Unirrigated agricultural field & 1070 & 1070 & 0 & 0 \\
\hline & & Irrigated paddy field & 0 & 0 & 0 & 0 \\
\hline & & Unirrigated paddy field & 0 & 0 & 0 & 0 \\
\hline & & Temporarily unused land & 3028 & 3018 & 0 & 10 \\
\hline \multirow[t]{5}{*}{10} & Tidore & Dry field/plantation & 59693 & 59603 & 0 & 90 \\
\hline & & Unirrigated agricultural field & 4816 & 12289 & 7473 & 0 \\
\hline & & Irrigated paddy field & 0 & 0 & 0 & 0 \\
\hline & & Unirrigated paddy field & 0 & 77 & 77 & 0 \\
\hline & & Temporarily unused land & 390 & 552 & 162 & 0 \\
\hline \multirow[t]{5}{*}{11} & North Maluku & Dry field/plantation & 202272 & 223526 & 21254 & 0 \\
\hline & & Unirrigated agricultural field & 65596 & 93903 & 28307 & 0 \\
\hline & & Irrigated paddy field & 8118 & 3832 & 0 & 4286 \\
\hline & & Unirrigated paddy field & 1360 & 3832 & 2472 & 0 \\
\hline & & Temporarily unused land & 18569 & 20754 & 2185 & 0 \\
\hline
\end{tabular}


TABLE 3. Population and land consumption per capita, according to Yeates (1980) in Dinas Lingkungan Hidup (2018).

\begin{tabular}{lrr} 
No. & Population & Land consumption per capita (ha/person) \\
\hline 1 & 10000 & 0.100 \\
2 & 25000 & 0.091 \\
3 & 50000 & 0.086 \\
4 & 100000 & 0.076 \\
5 & 250000 & 0.700 \\
6 & 500000 & 0.066 \\
7 & 1000000 & 0.061 \\
8 & 2000000 & 0.057 \\
\hline
\end{tabular}

be stable from 2010 to 2018, although there was a slight decline in 2018. The largest area of moor was in Sula, followed by Tidore. Dry fields or plantations in Sula are quite large because they form the main economic sector in the regency; many clove and coconut plantations are found in the area. Several coconut factories were previously established on the islands. Tidore also has a vast number of gardens compared with the other districts, due to the presence of coconut plantations, and plantations for spices in the region. As has been noted, the width of unirrigated agricultural fields and dry fields in North Maluku is far greater than the area of paddy fields, because of the condition of the land, namely that it is predominantly dry land. The decline in 2018 is possibly due to changes in non-agricultural land, such as for settlements and industries.

Changes in land use for agricultural land in North Maluku in 2010 to 2018 showed variations in each district; there was an increase in land area but there was also a lot of reduction in land area. Changes in the area of agricultural land use were caused by several factors, among them being changes from paddy land to non-paddy land, or changes to non-agricultural land. Table 2 shows how land use changed from 2010 to 2018.

West Halmahera was found to have a decrease in the area of dry fields and irrigated paddy fields, but an increase in the area of non-irrigated fields and unirrigated agricultural fields. This is possibly because of the government's policy guidance and other changes, such as settlements and so on. Central Halmahera experienced a reduction in irrigated paddy fields but an increase in other agricultural land areas, possibly due to land changes in non-agricultural areas. Meanwhile, Sula Islands experienced a reduction in the area of paddy fields and an increase in non-paddy fields; this was due to government policies that changed paddy fields into coconut plantations and fields to support a bet-

\section{Land Carrying Capacity in North Maluku}

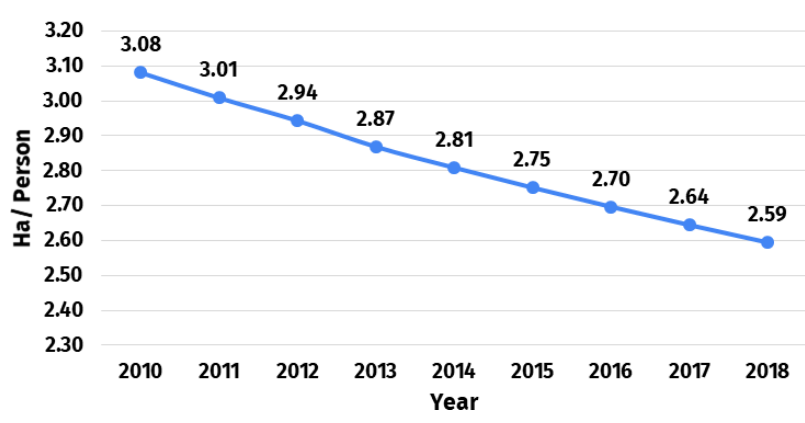

FIGURE 8. Land carrying capacity in North Maluku, 2010-2018. ter economic sector. South Halmahera experienced extensive reductions in irrigated paddy fields and experienced additions in other agricultural lands. North Halmahera experienced a reduction in the area of land for non-paddy fields and irrigated paddy fields, whereas for non-irrigated paddy fields there was an increase. Both East Halmahera and South Halmahera experienced a decrease in the area of irrigated paddy fields, but the area containing other agricultural lands increased, an effect that is influenced the district government's policy. Morotai Island was the result of the expansion of the North Halmahera district, so there are no data for this region in 2010. Taliabu Island was found to have a decrease in the area of irrigated paddy fields, while areas composed of the other agricultural lands increased and temporarily unused land decreased, indicating productivity in the district. Ternate was relatively unchanged in the use of agricultural land. Tidore experienced an increase in the area of dry fields and unirrigated paddy fields. In general, in North Maluku, there has been a decline in the area of irrigated paddy fields and the province has experienced a relatively high increase in other types of agricultural land.

\subsection{Land carrying capacity analysis}

Land carrying capacity refers to the ability of materials in a unit of land to support human needs in the form of land use, wherein the end goal is to meet human needs, especially that of food (Moniaga 2011). Meanwhile, land is defined as the part of the surface of the Earth where various activities take place and various structures enabling the support of human life are established. If land needs are not met, various problems will arise.

In North Maluku, for the nine-year period of 2010-2018, a decrease in the land carrying capacity trend was found. This is in line with the increasing population in the province each year. The average rate of decline in land carrying capacity in North Maluku Province was 6\% per year and the population growth rate was $2.1 \%$ per year. Table 3 shows the standard value of land carrying capacity and population size according to Yeates (1980) in Dinas Lingkungan Hidup (2018). If the land carrying capacity is lower than the determined value (land consumption per capita), it means that the population of the area has exceeded the threshold.

Overall, the land carrying capacity in this province has not yet exceeded the threshold because the average of land carrying capacity was 2.82 ha/person (Figure 8). On the other hand, the average number of population in North Maluku Province from 2010 to 2018 was greater than $1,000,000$. According to Table 3 , which shows land consumption per capita, only 0.0061 ha/person is required.

\section{Land Carrying Capacity in Each Regency/Municipality of North Maluku}

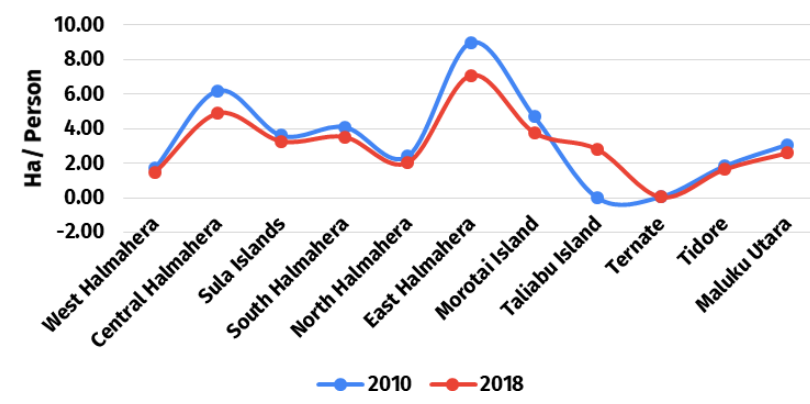

FIGURE 9. Land carrying capacity in each regency/municipality of North Maluku. 


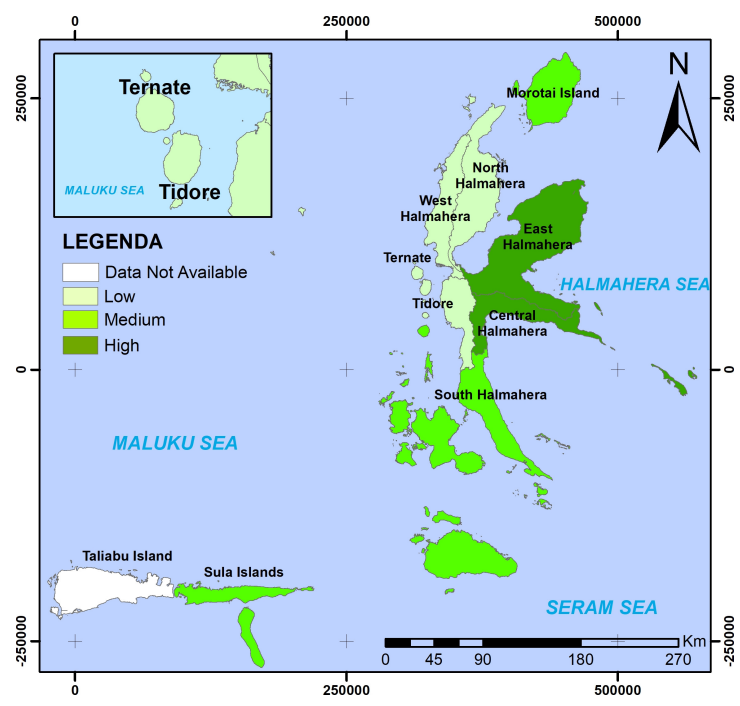

(a)

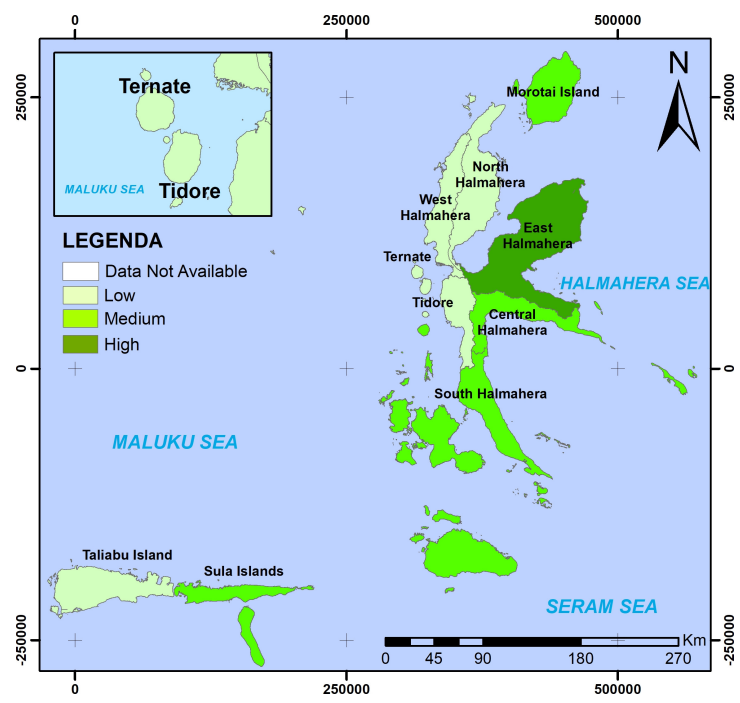

(b)

FIGURE 10. Map of land carrying capacity in North Maluku Province, (a) 2010 and (b) 2018.

North Maluku Province's land carrying capacity trend per regency of municipality in 2010 and 2018 can be seen in Figure 9. The trend of land carrying capacity in all regencies / municipalities decreased. However, in 2010, Taliabu Island's land carrying capacity data were not available because the regency was only established in 2012 . Nonetheless, generally, the land carrying capacity in each regency/municipality did not exceed the threshold. That is because the carrying capacity value exceeded 0 . Besides that, the total population in each regency/municipality was in the range of 50,000-100,000 people, which means it had a carrying capacity threshold of 0.061-0.086 ha/person.

A new category was created to classify the land carrying capacity using the standard deviation formula. In 2010, there were two districts included in the high category of land carrying capacity, namely Central Halmahera and East Halmahera. Sula Islands, South Halmahera, and Morotai Island were included in the medium category. There were four regencies/municipalities (West Halmahera, North Halmahera, Ternate, and Tidore Islands) included in the low category. Although a decrease in land carrying capacity was observed in 2018, this has not shifted the class of land carrying capacity in each regency/municipality. The differences between 2010 and
2018 were Taliabu Regency being included in the low category (from no category in 2010), and West Halmahera Regency lowering from the high to the medium category.

The highest carrying capacity of land in both 2010 and 2018 was in East Halmahera Regency and the lowest land carrying capacity is in Ternate Municipality. East Halmahera Regency is located in the eastern part of North Maluku Province. This regency is recorded as having the secondlargest land area in North Maluku, reaching $20.53 \%$ of the total land area. This region has a ratio of land area with the most balanced population among all the regencies/municipalities. Ternate Municipality has the lowest land carrying capacity because it had the second highest population in 2010 (185,705 people) and 2018 (228,105 people) with the smallest area (11,139 ha) compared with the other regencies/municipalities. The thing that most influences the land carrying capacity is the population. Factors that encourage population growth in an area are fertility and population migration. If fertility increases, it is a good sign of the health service as an indicator in measuring the success of local development. Furthermore, the presence of incoming migration will indicate the existence of an economic attraction or other factor motivating people to come into the region.

\section{CONCLUSIONS}

Land use in North Maluku Province for paddy fields was higher than non-paddy land use. Based on the approach to land resources balance in North Maluku Province in 2010 and 2018, there was a decrease in certain types of nonagricultural land use, namely that of protected forest by $150,895.79$ ha. Conversely, temporarily unused land and other non-agricultural land uses increased. Most forms of agricultural land use (dry fields/plantations, unirrigated agricultural fields, and unirrigated paddy fields) increased, with only the area used for irrigated paddy fields decreasing, by 4,286 ha. The land carrying capacity in North Maluku Province for the period of 2010-2018 was found to be declining, at a rate of $6 \%$ per year. This is due to the population increasing each year within a fixed land area. The highest carrying capacity of land in 2010 and 2018 was in East Halmahera Regency and the lowest land carrying capacity was in Ternate Municipality.

\section{ACKNOWLEDGMENTS}

The authors gratefully acknowledge the research support and guidance given by the lecturers of the Department of Environmental Geography, Faculty of Geography, Universitas Gadjah Mada. Thanks also to all of the institutions involved in providing the data and information necessary for this research.

\section{AUTHORS' CONTRIBUTIONS}

RF participated in the design of the study. FC and UK participated in collecting and analyzing the data. GR carried out the spatial output (maps). EP, ND, OS, and MR wrote the manuscript. All authors read and approved the final version of the manuscript.

\section{COMPETING INTERESTS}

All authors declare that we have no significant competing financial, professional, or personal interests that might have influenced the performance or presentation of the work described in this manuscript. 


\section{REFERENCES}

Agus F, Mulyani A. 2006. Judicious use of land resources for sustaining Indonesian rice self sufficiency. Rice industry, culture and environment, book 1. Sukamandi: Indonesian Agency for Agricultural Research and Development.

As-syakur A, Suarna IW, Adnyana IW, Rusna IW, Laksmiwati I, Diara IW. 2008. Studi perubahan penggunaan lahan di DAS Badung [Study of land use change in the Badung Watershed]. Jurnal Bumi Lestari. 10(2):200-208.

Ashari N. 2003. Tinjauan tentang alih fungsi lahan sawah ke non sawah dan dampaknya di Pulau Jawa [An overview of the conversion of paddy fields to non-paddy fields and its impacts in Java]. Forum penelitian Agro Ekonomi. 21(2):83. doi:10.21082/fae.v21n2.2003.83-98.

Bank Indonesia. 2013. Komoditas pertanian provinsi Indonesia [Indonesian provincial agricultural commodities]. https://www.bi.go.id/id/umkm/kelayakan/k omoditi/CariKomoditiUnggulan.aspx?skom=Karet.

Barkley PW. 1986. Barlowe, Raleigh. Land resource economics: the economics of real estate, 4th ed. Englewood Cliffs NJ: Prentice-Hall, 1986, x + 559 pp., \$ @@-@@31.95. Am J Agric Econ. 68(4):1030-1030. doi: $10.2307 / 1242159$.

Dinas Lingkungan Hidup. 2018. Laporan akhir penyusunan daya dukung dan daya tampung lingkungan Kabupaten Indramayu [The final report on the preparation of the environmental support and carrying capacity of Indramayu Regency]. Bandung: Dinas Lingkungan Hidup.

Fitrianingsih E. 2017. Tinjauan terhadap alih fungsi tanah pertanian ke non pertanian (permukiman) di Kecamatan Tomoni Kabupaten Luwu Timur [Review of the conversion of agricultural land to non-agricultural (settlements) in Tomoni District, East Luwu Regency; dissertation]. [Makassar]: Universitas Hasanudin Makassar.

Husin M, Herwangi Y. 2018. Analisis perubahan penggunaan lahan di kawasan perdesaan eks transmigrasi Kecamatan Wasile Kabupaten Halmahera Timur [Analysis of land use change in rural ex-transmigration areas, Wasile District, East Halmahera Regency]. Jurnal Planoearth. 3(2):72. doi:10.31764/jpe.v3i2.621.

Jaringan Advokasi Tambang. 2020 Mar 12. Maluku Utara bukan toilet [North Maluku is not a toilet; blog]. JATAM. [accessed 2020-03-26]. https://www.jatam.org/20 20/03/12/maluku-utara-bukan-toilet/.

Malut Post. 2003 Feb 17. Minggu depan Jikomalamo diaktifkan [Next week Jikomalamo is activated]. Malut Post. https://issuu.com/malutpost/docs/malut_post__1 8_februari_2017.

Moniaga VRB. 2011. Analisis daya dukung lahan pertanian [Analysis of the carrying capacity of agricultural land]. Agri-Sosioekonomi. 7(2):61-68. doi:10.35791/agrsosek. 7.2.2011.92.

Munibah K, Sitorus SRP, Rustiadi E, Gandasasmita K, Hartrisari. 2010. Dampak perubahan penggunaan lahan terhadap erosi di DAS Cidanau, Banten [Impact of land use change on erosion in the Cidanau Watershed, Banten]. Jurnal Tanah dan Iklim. 32:55-69.

Muta'ali L. 2014. Perencanaan pengembangan wilayah berbasis pengurangan risiko bencana [Regional development planning based on disaster risk reduction]. Yogyakarta: Badan Penerbit Fakultas Geografi.

Soil Research and Development Center. 2000. Atlas sumberdaya tanah eksplorasi Indonesia skala 1:1000000 [Atlas of Indonesian exploration land resources at a scale of 1: 1000000]. Bogor: Soil Research and Development Center.

Statistics Indonesia. 2011. Maluku Utara dalam angka 2011 [North Maluku in figures 2011]. Ternate: Statistics Indonesia.

Statistics Indonesia. 2016. Statistik penggunaan lahan Provinsi Maluku Utara 2015 [North Maluku Province land use statistics 2015]. Ternate: Statistics Indonesia.

Statistics Indonesia. 2019. Maluku Utara dalam angka 2019 [North Maluku in figures 2019]. Ternate: Statistics Indonesia.

Wahyunto. 2001. Analisis perubahan penggunaan lahan [Land use change analysis; dissertation]. [Yogyakarta]: Universitas Gadjah Mada.

Widjanarko BS, Pakpahan M, Rahardjono B, Putu S. 2006. Aspek pertanahan dalam pengendalian alih fungsi lahan pertanian (sawah) [Land aspects in controlling the conversion of agricultural land (paddy fields)]. Prosiding Seminar Nasional Multifungsi Lahan Sawah:19-28.

Yeates M. 1980. The north american cities. Ontario: Queen. 